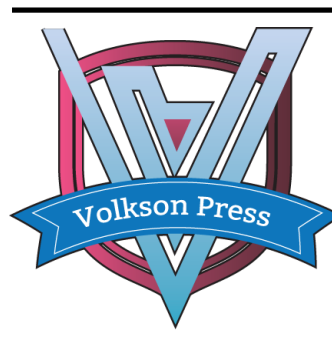

Contents List available at VOLKSON PRESS

New Materials and Intelligent Manufacturing (NMIM) DOI : http://doi.org/10.26480/icnmim.01.2018.443.445

Journal Homepage: https://topicsonchemeng.org.my/

ISBN: 978-1-948012-12-6

\title{
SYNTHESIS AND PHOTOCATALYSIS OF CUPROUS OXIDE NANO-SPHERES IN AQUEOUS
}

\author{
Qihui Shen, Hanliang Gao, Xinchen Xu and Yan Liu* \\ Department of Chemistry and Pharmaceutical Engineering, Jilin Institute of Chemical Technology, No.45 Chengde Street, Jilin 132022, P. R. China. \\ *Corresponding Author E-mail: liuyanjlu@126.com.
}

This is an open access article distributed under the Creative Commons Attribution License, which permits unrestricted use, distribution, and reproduction in any medium, provided the original work is properly cited

\section{ARTICLE DETAILS}

Article History:

Received 26 June 2018 Accepted 2 July 2018

Available online 1 August 2018

\section{ABSTRACT}

Cuprous oxide $\left(\mathrm{Cu}_{2} \mathrm{O}\right)$ nanocrystallites were successfully prepared by using hydrazine hydrate as reducing agent and polyvinyl pyrrolidone (PVP) as the capping agent in aqueous phase, which was proved to be a green and convenient method for the synthesis of $\mathrm{Cu}_{2} \mathrm{O}$ Nano-spheres. Photocatalytic decolorization of Methyl Orange in aqueous $\mathrm{Cu}_{2} \mathrm{O}$ suspensions was investigated. Using X-ray diffraction, scanning electron microscope, High Resolution Transmission Electron Microscopy characterized the samples and UV-vis Spectroscopy was employed to investigate the photocatalysis behavior of the $\mathrm{Cu}_{2} \mathrm{O}$ samples.

\section{KEYWORDS}

nanocrystallites, cuprous oxide, photocatalysis.

\section{INTRODUCTION}

Based on a study, approximately $80 \%$ of world energy consumption is derived from fossil fuels [1]. However, reserves of fossil fuel are not abundant and have posed significant concerns regarding widespread environmental pollution [2]. For addressing these problems, many proposals have been studied for the clean energy developments in which the fossil fuels are replaced by solar cells, secondary cells and photoelectron-chemical cells [3-5]. Over the past few years, semiconductor photocatalysts have attracted considerable attention due to their challenging potential for resolving the current energy and environmental problems [6]. According to a study, cuprous oxide $\left(\mathrm{Cu}_{2} \mathrm{O}\right)$ is an attractive alternative for widespread use in future photovoltaic devices owing to its direct band gap of approximately $2.2 \mathrm{eV}$, a high optical absorption coefficient, and its earth abundant, nontoxic constituents [710]. $\mathrm{Cu}_{2} \mathrm{O}$, a p-type semiconductor metal oxide, has received extensive attention owing to its remarkable cost advantage compared to noble metals, as well as its suitable properties in photocatalysis, solar energy conversion, and catalysis [11-13]. The synthesis of $\mathrm{Cu}_{2} \mathrm{O}$ has attracted much attention in recent years. To the best of our knowledge, a large number of syntheses of $\mathrm{Cu}_{2} \mathrm{O}$ with various morphologies had been reported. In this work, we reported an easier, more convenient and nontoxic method to preparing $\mathrm{Cu}_{2} \mathrm{O}$ in water by used hydrazine hydrate as reducing agent. The concentration of hydrazine hydrate effect the synthesis of $\mathrm{Cu}_{2} \mathrm{O}$, and polyvinyl pyrrolidone (PVP) as the capping agent influent the morphologies. Moreover, photocatalytic activities of the resulted $\mathrm{Cu}_{2} \mathrm{O}$ could be used to photodegrade methyl orange (MO).

\section{EXPERIMENTAL DETAILS}

\subsection{Materials}

$\mathrm{CuSO}_{4} .5 \mathrm{H}_{2} \mathrm{O}$ and hydrazine hydrate $(85 \%)$ were purchased from Tianjin, China. PVP and MO were acquired from Shanghai, China. All chemicals were used without further purification.

\subsection{Synthesis of cuprous oxide $\left(\mathrm{Cu}_{2} \mathrm{O}\right)$ nanocrystals}

In a typical procedure, $0.04 \mathrm{~g} \mathrm{CuSO}_{4} \cdot 5 \mathrm{H}_{2} \mathrm{O}, 0.5 \mathrm{~g}$ PVP were dissolved in 50 $\mathrm{mL} \mathrm{H}_{2} \mathrm{O}$ under stirring, then $100 \sim 310 \mu$ l hydrazine hydrate was poured under the same constraints, respectively. The mixture was continued stirring for 30 minutes. After centrifuging, the precipitate was filtered with ethanol then dried in vacuum drying chamber.

\subsection{Characterization of cuprous oxide $\left(\mathrm{Cu}_{2} \mathrm{O}\right)$ nanocrystals}

The samples were characterized for their phase purity and crystallinity by $\mathrm{X}$-ray diffractometer with angles ranging from 20 to $80^{\circ}$, and the operating current and voltage were maintained at $40 \mathrm{~mA}$ and $30 \mathrm{kV}$, respectively. The size and morphology of the $\mathrm{Cu}_{2} \mathrm{O}$ nanocrystals were analyzed via TEM and SEM.

\subsection{Photocatalytic decolorization of MO}

Photocatalytic decolorization of MO was carried out in glass vial with cycled cool water under $300 \mathrm{~W}$ mercury lamp, the degradating percentage of MO was calculated by absorption maxima $(\lambda=463 \mathrm{~nm})$, obtained using PE Lambda 750 spectrophotometer.

\section{RESULTS AND DISCUSSION}

\subsection{Characterization}

The XRD spectra of the samples displayed they were cuprous oxide $\left(\mathrm{Cu}_{2} \mathrm{O}\right)$ when the hydrazine hydrate was poured 100-290 $\mu \mathrm{l}$, and according to the Scherrer formula, we can draw a conclusion that the diameters of cuprous oxide $\left(\mathrm{Cu}_{2} \mathrm{O}\right)$ are about $10 \mathrm{~nm}$. But the samples were reduced to $\mathrm{Cu}$ directly (Figure 1d when the hydrazine hydrate was poured more than $290 \mu$.

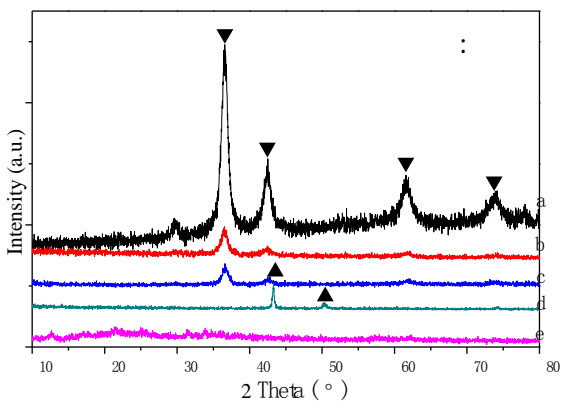

Figure 1: XRD pattern of $\mathrm{Cu}_{2} \mathrm{O}$ prepared with different hydrazine hydrate. (a: 100, b: 200, c: 290, d: $300 \mu \mathrm{l}$, e: after photocatalytic decolorized 20 cycles of sample a) 
From SEM image (fig 2a), the $\mathrm{Cu}_{2} \mathrm{O}$ spherical particles with a diameter of about $0.5 \mu \mathrm{m}$ can be observed. The results had significant differences with the calculation from XRD, maybe caused by PVP encapsulated a large number of $\mathrm{Cu}_{2} \mathrm{O}$ nanoparticles. The HRTEM images of $\mathrm{Cu}_{2} \mathrm{O}$ showed the sample has a grave adhesion phenomenon due to the presence of PVP, whereas it has a good lattice (Figure $2 \mathrm{~b}$ ).

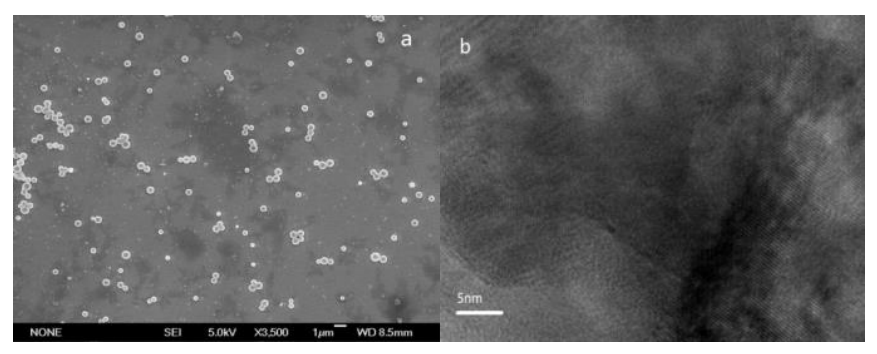

Figure 2: SEM (a) and HRTEM (b) images of $\mathrm{Cu}_{2} \mathrm{O}$.

The survey spectra showed $\mathrm{Cu} 2 \mathrm{p}$ electrons can be identified at the twin peaks of $933 \mathrm{eV}$ and $953 \mathrm{eV}$, the $\mathrm{C} 1 \mathrm{~s}$ electrons at about $284 \mathrm{eV}$ and the $01 \mathrm{~s}$ electrons can be readily found at around $530 \mathrm{eV}$ (Figure 3a). Highresolution scans of the Cu2p electrons are depicted in figure $3 \mathrm{~b}$, from which two main peaks may be identified at around 933 and $953 \mathrm{eV}$. These may be assigned to the $\mathrm{Cu} 2 \mathrm{p} 3 / 2$ and $\mathrm{Cu} 2 \mathrm{p} 1 / 2$ electrons, respectively, which are consistent with cuprous oxide.
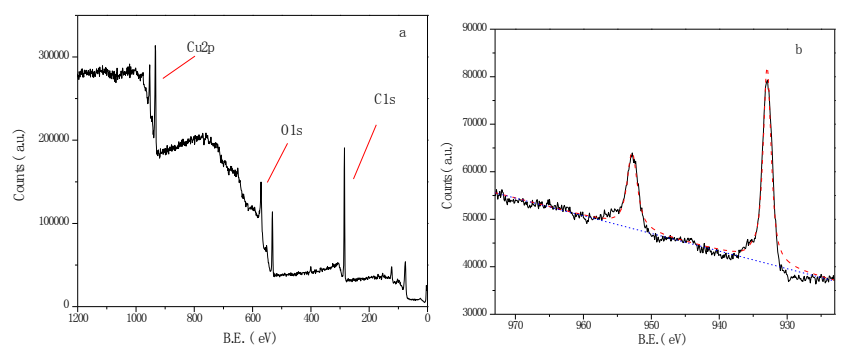

Figure 3: Survey (a) and $\mathrm{Cu} 2 \mathrm{p}$ (b) XPS spectra of $\mathrm{Cu}_{2} \mathrm{O}$.

\subsection{Photocatalytic properties}

Different $\mathrm{Cu}_{2} \mathrm{O}(10,20,30 \mathrm{mg})$ were added to $10^{-4} \mathrm{~mol} / \mathrm{L}$ MO respectively. Figure 3 shows the dosage effect of $\mathrm{Cu}_{2} \mathrm{O}$. The more dosage of $\mathrm{Cu}_{2} \mathrm{O}$ we added the shorter time was used.

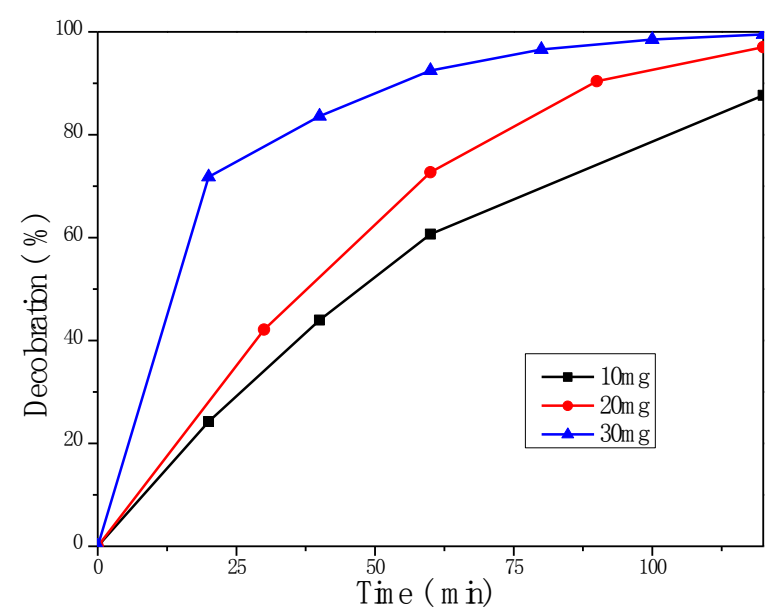

Figure 4: Photo decoloration Catalytic efficiency of 10, 20, $30 \mathrm{mg} \mathrm{Cu}_{2} \mathrm{O}$.

$30 \mathrm{mg} \mathrm{Cu} 2 \mathrm{O}$ was added into $10^{-3}, 10^{-4}, 10^{-5} \mathrm{~mol} / \mathrm{L} \mathrm{MO}$, respectively. Figure 4 shows the effect of MO. The lower density of MO result the higher catalytic efficiency.

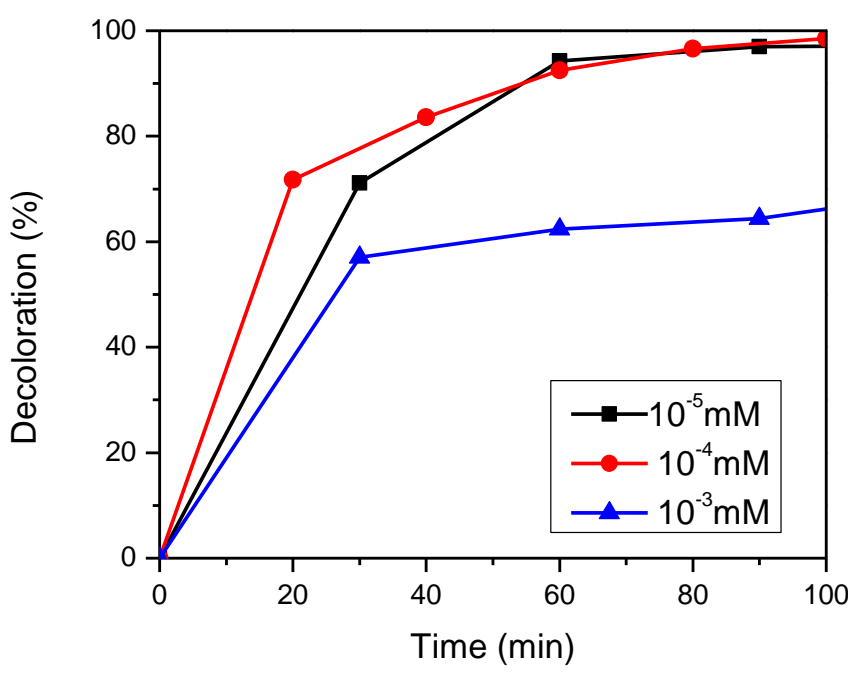

Figure 5: Catalytic efficiency of $10^{-3}, 10^{-4}, 10^{-5} \mathrm{~mol} / \mathrm{L} \mathrm{MO}$.

We used $10^{-4} \mathrm{~mol} / \mathrm{L} \mathrm{MO}$ and added $\mathrm{Cu}_{2} \mathrm{O}$ to test the catalysis life of catalyst. The decoloration was near $90 \%$ after the catalyst catalysis 24 cycles (Fig. 6)

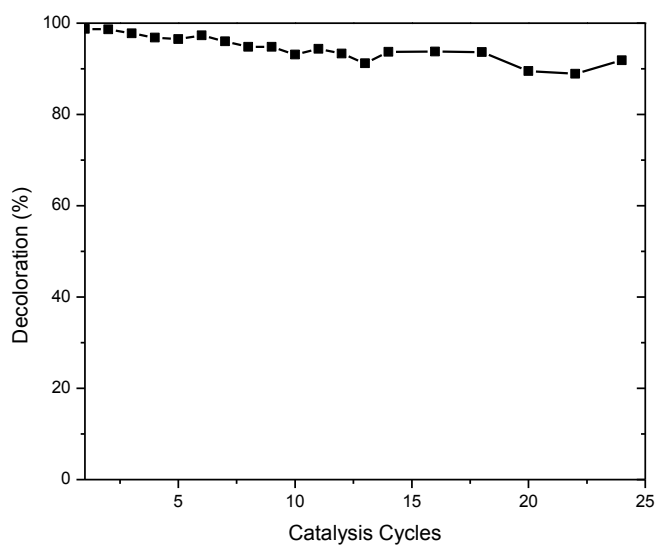

Figure 6: The catalysis life of $\mathrm{Cu}_{2} \mathrm{O}$

\section{CONCLUSIONS}

In this work, $\mathrm{Cu}_{2} \mathrm{O}$ was prepared when the hydrazine hydrate was added 100-290 $\mu \mathrm{l}$, and $\mathrm{Cu}$ was obtained when the hydrazine hydrate was added more. The $\mathrm{Cu}_{2} \mathrm{O}$ particles had good lattice and the diameters were less than $100 \mathrm{~nm}$ and had good catalytic activity and could be used more than 24 cycles.

\section{ACKNOWLEDGEMENTS}

This work was supported by the National Sciences Foundation of China (21301066, 21371068, 21605056)

\section{REFERENCES}

[1] Qian, F., Wang, G., Li, Y. 2010. Solar-driven microbial photoelectron chemical cells with a nanowire photocathode, Nano Letters, 10, 46864691.

[2] Chiang, C., Epstein, J., Brown, A., Munday, J.N., Culver, J.N., Ehrman, S. 2012. Biological templates for antireflective current collectors for photoelectron chemical cell applications, Nano Letters, 12, 6005-6011.

[3] Cui, J., Gibson, U.J. 2010. A simple two-step electrodeposition of Cu20/ZnO nanopillar solar cells, Journal of Physical Chemistry C, 114, 6408-6412.

[4] Akimoto, K., Ishizuka, S., Yanagita, M., Nawa, Y., Paul, G.K., Sakurai, T. 2006. Thin film deposition of $\mathrm{Cu}_{2} \mathrm{O}$ and application for solar cells, Solar Energy, 80, 715-722. 
[5] Zhang, Z., Dua, R., Zhang, L., Zhu, H., Zhang, H., Wang, P. 2013. Carbonlayer-protected cuprous oxide nanowire arrays for efficient water reduction, ACS Nano, 7, 1709-1717.

[6] Yang, R., Ma, F., Tao, T. 2013. $\mathrm{Zn}^{2+}$ assisted synthesis of concave $\mathrm{Cu}_{2} \mathrm{O}$ crystals and enhanced photocatalytic properties, Catalysis Communications, 42, 109-112.

[7] Musa, A.O., Akomolafe, T., Carter, M.J. 1998. Production of cuprous oxide, a solar cell material, by thermal oxidation and a study of its physical and electrical properties, Solar Energy Materials and Solar Cells, 51, 305316.

[8] Izaki, M., Shinagawa, T., Mizuno, K.T., Ida, Y., Inaba, M., Tasaka, A. 2007. Electrochemically constructed $\mathrm{p}-\mathrm{Cu}_{2} \mathrm{O} / \mathrm{n}-\mathrm{ZnO}$ heterojunction diode for photovoltaic device, Journal of Physics D, 40, 3326-3329.

[9] Mittiga, A., Salza, E., Sarto, F., Tucci, M., Vasanthi, R. 2006. Heterojunction solar cellwith $2 \%$ efficiency based on a $\mathrm{Cu}_{2} \mathrm{O}$ substrate, Applied Physics Letters, 88, 163502.
[10] Leng, M., Liu, M.Z., Zhang, Y.B., Wang, Z.Q., Yu, C., Yang, X.G., Zhang, H.J., Wang, C. 2010. Polyhedral 50-Facet $\mathrm{Cu}_{2} \mathrm{O}$ Microcrystals Partially Enclosed by 311 High-Index Planes: Synthesis and Enhanced Catalytic CO Oxidation Activity, Journal of the American Chemical Society, 132, 17084-17087.

[11] Shi, H., Yu, K., Sun, F., Zhu, Z. 2012. Controllable synthesis of novel $\mathrm{Cu}_{2} \mathrm{O}$ micro/nano-crystals and their photoluminescence, photocatalytic and field emission properties, Crystal Engineering Community, 14, 278285.

[12] Shao, F., Sun, J., Gao, L., Luo, J., Liu, Y., Yang, S. 2012. High Efficiency Semiconductor-Liquid Junction Solar Cells based on $\mathrm{Cu}_{-} \mathrm{Cu}_{2} \mathrm{O}$, Advanced Functional Materials, 22, 3907-3915.

[13] Li, L., Nan, C., Peng, Q., Li, Y. 2012. Selective Synthesis of $\mathrm{Cu}_{2} \mathrm{O}$ Nanocrystals as Shape-Dependent Catalysts for Oxidation. Chemistry: A European Journal, 18, 10491-10496. 